\title{
Opetusalan asiantuntijoiden
}

\section{käsityksiä opettajan pedagogisesta innovatiivisuudesta}

\author{
REIJO SILTALA, JARKKO ALAJÄÄSKI, SOILI KESKINEN \& ANU TENHUNEN
}

\begin{abstract}
Innovatiivisuudelle ei ole olemassa yhtä yksittäistä määritelmää, vaan innovatiivisuus elää käsitteenä tilanteen ja lähtökohdan mukaan. Se voidaan nähdä yksilön, yhteisön tai yhteiskunnan ominaisuudeksi. Yleensä sen katsotaan olevan sitä laadukkaampaa, mitä laadukkaammaksi talous, tekniikka ja yhteisön kehitys muodostuvat (Piva \& Vivarelli 2007). Useimmiten innovatiivisuus tulkitaan käytännön kekseliäisyydeksi ja käytännön tasolla toteutuvaksi luovuudeksi. Tässä artikkelissa pohditaan sitä, minkälaisia käsityksiä opetusalan asiantuntijoilla on opettajan innovatiivisen toiminnan piirteistä.
\end{abstract}

Yhesent hteiskunnallisella tasolla innovatiivisuudesta tuodaan esille yleensä kaksi piirrettä: kyky luoda uutta tietämystä tutkimuksen avulla ja kyky luoda uudenlaista liiketoimintaa. Inkinen (2000) on ehdottanut innovaatio-käsitteenkin kääntämistä "uudisteeksi” ja sitä kautta tarkasteltuna innovatiivisuus uudistusten vastaanottamisena tulee paremmin ymmärretyksi.

Yleisesti tarkasteltuna innovatiivisuus on eräänlaista avoimuutta uusia ideoita kohtaan. Toisaalta innovatiivista yhteisöä kuvaa kyky hallinnolliseen joustavuuteen ja monitasoiseen reagointiin (Georgellis, Joyce \& Woods 2000). Joustavuutta ja sosiaalisia taitoja edellytetään myös innovatiiviselta henkilöltä. Perinteinen keksijä luovine ideoineen, ilman sosiaalisia kykyjä, ei näin ollen välttämättä ole innovatiivinen, vaan vasta kekseliäisyyteen liitetyt sosiaaliset kontaktit luovat innovatiivisuutta. Innovatiivisuutta voidaankin pitää luovan energian toteuttamisena käytännön tasolla. Siihen liittyy yksilön, organisaation tai kansan kyky pohtia uudella tavalla toimintojaan ja ympäristöään ja kehittää sitä. Se on siis kykyä omaksua ja kehittää uusia ideoita, prosesseja ja tuotteita. (Lam 2004; Lam \& Lundvall 2007)

\section{Innovatiivisuuden häilyvä käsite opetusalalla}

Innovatiivisuus-käsitteen liike-elämätaustasta johtuen sitä on käytetty suppeammin ja vähemmän aikaa kasvatusalan diskurssissa. Kasvatuksessa innovatiivisuus näyttää saaneen myös jossain määrin erisävyisen merkityksen kuin sillä on alun perin liike-elämän puolella ollut. Opetus- ja kasvatusalan innovatiivisuus ei ainakaan vielä ole saanut erityisen pysyvää määritelmää. Innovatiivisuudella kuvataan usein uutta tapaa opettaa, uudeksi koettua opetusmetodia tai tavallista tehokkaampaa kehitysohjelmaa (Cherniss \& Fishman 2004; Jackson \& Kelley 2006; Nali \& Lorenzini 2004; Tenhunen, Siltala \& Keskinen 2009). Usein kasvatus- ja opetusalan innovatiivisuus on ymmärretty myös joko teknisiksi uudisteiksi tai voimakkaan metodiorientoituneesti, kuten esimerkiksi (1) elämykselliseksi oppimiseksi, (2) roolipeleiksi, (3) kilpailuiksi ja opetuspeleiksi, (4) stimuloivaksi aineistoiksi, (5) aivomyrskyksi tai (6) erilaisiksi ryhmämetodeiksi. (Brown 2006; Handfield-Jones, Nashmith, Steinert \& Lawn 1993). Ellis (2005) on kasvatuksen innovaatioita tarkastelevassa teoksessaan maininnut lisäksi tiimioppimisen ja monikulttuurisen kasvatuksen. 
Innovaatioiden diffuusio- eli levittäytymistutkimuksissa tarkastellaan innovaation käyttöönottoa ja leviämistä yhteiskunnan eri osa-alueilla. Rogers (2003) määrittelee innovaation diffuusion prosessiksi, jossa innovaatio leviää ihmisten ja ihmisryhmien välillä. Rohkeasti soveltaen mm. koulumaailman innovaatioiden omaksumista voidaan tarkastella Clarkin (2001) esittämän muutosvastarinta-käsitteen näkökulmasta. Koulujen perinteissä pysyminen ja muutosvastarinta johtuvat ainakin osittain ihmisen luonnollisesta halusta pysytellä tutussa ja turvallisessa. Paavola (2007) on korostanut vielä perimmäisempää syytä: koulu on organisaationa erityisessä asemassa, koska se on rakennettu kasvatustehtävään ja perinteiden siirtämiseen. Olisikin pohdittava, mikä osa muutosvastarinnasta liittyy pyrkimykseen puolustaa koulun perustehtävää ja milloin jotakin muuta seikkaa, kuten opettajan saavutettuja asemia tai yleisesti oppimisen kannalta epäedullisia ratkaisuja. Fullan (1997) on kritisoinut koulun tavallista perusongelmaa: usein kun koulun pitäisi muuttaa omaa toimintaansa, aletaan koulun toiminnan sijaan pohtia, miten koteja, esimiehiä tai yhteiskuntaa tulisi muuttaa. Koska muutosvastarinta ja siihen vaikuttaminen ovat hyvin selkeästi yhteydessä innovaation diffuusioon, on sen eri tasot huomioitava.

Venkatesh, Morris, Davis ja Davis (2003) ovat luoneet innovatiivisuuteen laajemminkin käyttökelpoisen teorian pohtiessaan teknologian käyttöönottoa ja käyttöä. Ilmiössä on neljä päänäkökulmaa: (1) Suorituskykyodotuksissa tarkastellaan sitä, kuinka paljon henkilö uskoo uudistuksen auttavan häntä edistämään työhön liittyvää suorituskykyä. (2) Vaivattomuusodotuksissa tarkastelun kohteena on se, miten helpoksi uutuuden käyttöönotto ajatellaan. (3) Sosiaaliset vaikutukset liittyvät siihen, minkä verran yksilö ajattelee merkityksellisten henkilöiden olevan sitä mieltä, että uutuutta tulisi käyttää. (4) Tukevat olosuhteet liittyvät puolestaan organisaation rakenteisiin ja siihen, minkälaisia muita rakenteita uutuuden käyttöönoton tueksi on olemassa (Venkatesh ym. 2003). Myös opetusalalla joudutaan usein vastaamaan nimenomaan siihen, millä tavoin uudistus auttaa tavoitteisiin pyrkimisessä ja miten paljon vaivaa on nähtävä uudistuksen käyttöön ottamiseksi. Opetusalalla lisäksi usein koetaan painetta ulkoapäin tulevien uudisteiden käyttöönotosta ja organisaatio nähdään pikemminkin muutosvastarintaiseksi (Siltala ym. 2006).
Sukupuolesta ja asemasta tai roolista organisaatiossa riippumattomia tasa-arvoisia mahdollisuuksia on pidetty myös perusedellytyksinä innovatiivisuuden kehittymiselle (Kuoppala, Virtanen, Anttiroiko \& Pantzar 2003). Kun lisäksi useissa tutkimuksissa (ks. esim. Sheldon, Ryan, Rawshorne \& Ilardi 1997; Singh, De Noble \& Kalousova 2002) on tuotu esiin, että avoimuuteen suoraan liittyvässä innovatiivisuudessa persoonallisuuden tasolla ei ole mainittavasti sukupuolten välisiä eroja, on mielenkiintoista selvittää, missä määrin sukupuolten välillä on eroa siinä, miten opettajan innovatiivisen toiminnan piirteet hahmotetaan. Jotta voidaan tukea innovatiivisuutta, on hahmotettava siihen liittyviä käsitteitä.

Kaiken kaikkiaan innovatiivisuus opetus- ja kasvatusalalla on tulkittu tieteellisessä keskustelussa melko mullistuksellisena ilmiönä eikä yksittäisen opettajan tuottamiin, vähemmän radikaaleihin innovaatioihin ole kohdistettu niinkään huomiota. Tämän käsillä olevan tutkimuksen tavoitteena oli tutkia, miten kasvatus- ja opetusalan käytännön asiantuntijat ymmärtävät innovatiivisuuden opettajan toiminnassa. Siksi on huomioitava myös käsityksiin vaikuttavat tekijät. Pohjimmiltaan vallitseviin käsityksiin vaikuttavat sosiaaliset arvot, joilla tarkoitetaan ympäristöstä opittuja, pysyviä ja tavoitteellisia valintataipumuksia. Käsityksiin vaikuttavat myös asenteet, joiden kehittyminen perustuu aiempiin kokemuksiin. Asenteilla on ennakoiva luonne ja ne voivat olla joko myönteisiä tai kielteisiä. Arvot ja asenteet ovat usein taustalla myös tilanteessa, jossa innovaation diffuusiossa tapahtuu joko hyväksyminen tai hylkääminen (Kivisaari 2004; Rogers 2003). Opettajan innovatiivisuus-käsityksiä ja niiden vaikutuksia opetuksen ja kasvatuksen innovaatioiden leviämiseen on tutkittu erittäin vähän, eikä näissäkään harvoissa tutkimuksissa ole huomioitu innovatiivisuuteen vaikuttavia taustatekijöitä kuten sukupuolta tai opettajan toimialaa.

Tässä kuvatussa tutkimuksessa innovatiivisuuden yleisesti ja myös opettajan toiminnan innovatiivisuuden oletettiin olevan positiivisia ilmiöitä. Niihin liittyvien asenteiden ennakoitiin olevan myös valtaosin positiivisia. Innovatiivisuus ymmärrettiin luovuuden ilmentymiseksi käytännön toiminnassa. Arvoja tarkasteltaessa olisi pohdittava, ovatko esimerkiksi koulun kasvatus- ja opetustarkoitukset ristiriidassa innovatiivisen opettajan toiminnan kanssa. Päivittäisessä keskustelussa innovaatiot ja innovatiivisuus toistuvat 
usein ja innovatiiviseen toimintaan on pyritty ohjaamaan useissa laajoissakin strategioissa, esimerkiksi opetusministeriön (2007) koulutusta ja tutkimusta tarkastelevassa suunnitelmassa. On siksi tarpeellista tutkia, minkälaisia innovatiivisuus-käsityksiä opetusalalla vallitsee.

\section{Tutkimusongelmat}

Tutkimusongelmat olivat seuraavat:

(i) Mitä ominaisuuksia pidetään tärkeinä ja mitä vähemmän tärkeinä opettajan innovatiivisuudessa? Eroavatko eri vastaajaryhmien (opettajaopiskelijat, perusasteen opettajat ja korkea-asteen opettajat) käsitykset toisistaan?

(ii) Minkälaisia sukupuolten välisiä eroja on havaittavissa siinä, minkälaista opettajan toimintaa pidetään innovatiivisena?

\section{Tutkimusaineisto ja -menetelmät}

Kevään ja kesän 2008 aikana kerättiin opetusalan asiantuntijoilta $(n=485)$ vastaukset kyselyyn, jossa oli 9 taustamuuttujakysymystä ja 57 viisiluokkaisen Likert-asteikon (täysin samaa mieltä - samaa mieltä - en osaa sanoa - eri mieltä - täysin eri mieltä) väittämää innovatiivisuudesta. Väittämät voidaan jakaa sisällön perusteella neljään ryhmään: 1) ryhmä-, 2) oppilas-, 3) keino- ja 4) opettajaväittämät. Väittämille oli johdantona "Kun opettaja toimii innovatiivisesti, hänen toimintaansa voi kuvailla seuraavasti:”. Tämän avulla haettiin vastauksia esimerkiksi väittämiin: "Hän korostaa yhteistyön merkitystä työyhteisössä” (ryhmäväittämät), "Hän toimii oppilaskeskeisesti" (oppilasväittämät), ”Hän käyttää yhteistoiminnallisia oppimismenetelmiä" (keinoväittämät) ja "Hän on sitoutunut vahvasti opetustyöhön" (opettajaväittämät). Valtaosa (76 \%) kaikista kyselyyn vastanneista täytti paperisen kyselylomakkeen ja pienempi osa (24\%) sen kanssa identtisen web-lomakkeen.

Kyselyn väittämät perustuivat sekä tutkijoiden aiempiin, pääosin liike-elämän innovaatioihin kohdistuneisiin tutkimuksiin (Siltala, Keskinen, Suomala \& Taatila 2008; Siltala, Suomala, Taatila \& Keskinen 2007; Suomala, Taatila, Siltala \& Keskinen 2006) että laajaan käsitekatsaukseen liiketaloudellisista innovaatioista ja innovatiivisuudes- ta sekä opetus- ja kasvatusalan tutkimuksiin aihepiiristä.

Kyselyyn osallistuneet olivat 1) opettaja-opiskelijoita ( $\mathrm{n}=54), 2)$ perusasteen (peruskoulu ja lukio) opettajia (n=228) ja 3) korkea-asteen (yliopistollinen opettajankoulutus, ammattikorkeakoulu) opettajia ( $\mathrm{n}=133)$. Tässä tutkimuksessa pyrittiin mahdollisimman erilaisten opetusalan tahojen mukaan saamiseen ja mahdollisimman suureen kyselyyn vastanneiden joukkoon, mutta tavoitteena ei ollut hankkia yleistettävää tutkimusmateriaalia.

Opettajaopiskelijoiden vastaukset kerättiin luentojen tai oppituntien yhteydessä, eikä opiskelijoista kukaan kieltäytynyt vastaamasta kysymyksiin.

Perusopettajien osalta tutkijat loivat kontaktit kouluihin, joihin sovittiin tapaamisaika sellaiseen työpäivän tilanteeseen, jossa mahdollisimman suuri osa opetushenkilökunnasta on yhtä aikaa läsnä. Usein kyseessä oli viikoittainen kokous tai pienemmissä kouluissa esimerkiksi yhteinen iltapäivän välitunti, jolle opettajien oli tapana kokoontua. Perusopettaja-aineistoa vahvistettiin tutkijoiden omien verkostojen avulla niin, että saatiin vastauksia sähköiseen vastauslomakkeeseen. Sähköiseen lomakkeeseen vastaajien osallistumisprosenttia ei ollut mahdollista laskea.

Ammattikorkeakouluopettajat osallistuivat kyselyyn erään kokousmatkansa yhteydessä ja lisäksi tätä aineistoa täydennettiin sähköisen vastauslomakkeen avulla. Opettajankouluttajat vastasivat joko paperiseen tai sähköiseen vastauslomakkeeseen, eikä myöskään heidän osaltaan voitu laskea osallistumisprosenttia.

Tutkimuksessamme tarkastellaan alkuperäisen vastaajajoukon sellaisten vastaajien osajoukkoa ( $\mathrm{n}=415)$, jotka toimivat kyselyhetkellä peruskoulun, toisen asteen oppilaitoksen tai korkea-asteen opettajina tai jotka olivat opettajakokemusta omaavia opettajaopiskelijoita. Kaikkiaan kyselyyn vastanneita oli 485 ja näistä 428:lla oli opettajakokemusta. Heistä 13 ei kuitenkaan työskennellyt kyselyhetkellä opettajana tai ollut opettajaopiskelija (esimerkiksi tutkijat ja työelämän ulkopuolella olevat). Vastaajista enemmistö oli naisia (Taulukko 1).

Aineiston tilastoanalyysit suoritettiin SPSS-tilasto-ohjelmalla. Ryhmien keskiarvojen eroja analysoitiin t-testillä (miehet/naiset) ja yksisuuntaisella varianssianalyysillä (opettajaopiskelijat/perusasteen opettajat/korkea-asteen opettajat). Ky- 
TAULUKKO 1. Vastaajien opettaja-asema sukupuolen suhteen

\begin{tabular}{|lllll|}
\hline \multicolumn{5}{|l|}{ Opettaja-asema } \\
Sukupuoli & Opettaja- & Perusasteen & Korkea-asteen & Yhteensä(*) \\
& opiskelijat & opettajat & opettajat & \\
Mies & 25 & 73 & 40 & 138 \\
Nainen & 29 & 153 & 93 & 275 \\
Yhteensä & 54 & 226 & 133 & $413\left(^{*}\right)$ \\
(*) Kaksi vastaajaa ei vastannut sukupuolta koskevaan taustakysymykseen
\end{tabular}

selyyn vastanneiden ryhmät ovat niin suuria, että näillä menetelmillä tehtäviä ryhmäerojen merkitsevyysarvioita voidaan pitää luotettavina siitä riippumatta, ovatko populaatiojakaumat normaalijakaumia. Populaatiovarianssien yhtäsuuruudet testattiin Levenen testillä. Koko aineistolla $(n=415)$ kaikista 57 innovatiivisuusväittämästä laskettu Cronbach’n alfakertoimen arvo oli 0,919.

\section{TULOKSET}

\section{Opettajan innovatiivisuutta parhaiten kuvaavat ja heikoiten kuvaavat ominaisuudet}

Kyselyyn vastanneet korostivat ammattitaitoa ja pedagogista osaamista sekä kekseliäisyyttä innovatiivisen opettajan toiminnan piirteinä. Myös opetusmenetelmien monipuolisuus ja uudistumiskyky korostuivat vastauksissa. Heikoiten opettajan innovatiivista toimintaa kuvasi perinteisen tyylinen autoritäärisyys, jossa opetustyössä sovel- letaan vain yhtä tai muutamia opetusmetodeita.

Kuvioissa 1 ja 2 on nähtävissä kuvailevat diagrammit viidestä parhaiten opettajan innovatiivista toimintaa kuvaavasta (suurimmat vastausten keskiarvot) ja viidestä heikoiten kuvaavasta piirteestä (pienimmät vastausten keskiarvot).

Parhaiten (suurin vastauskeskiarvo) opettajan innovatiivista toimintaa kuvaavaksi piirteeksi osoittautui kyky uudistaa opetusmenetelmiä. Eri toimintatapojen yhdistäminen korostui erityisesti korkea-asteen opettajien vastauksissa, mutta myös muut vastaajaryhmät pitivät sitä hyvin tärkeänä. Kekseliäisyyttä ja pedagogista osaamista pidettiin tärkeinä innovatiivisen opettajan toiminnan piirteinä.

\section{Innovatiivinen opettaja}

(I14) uudistaa opetusmenetelmiään,

(I15) liittää yhteen erilaisia toimintatapoja,

(I18) on kekseliäs,

(I49) käyttää monipuolisesti eri opetusmenetelmiä, (I56) on pedagogisesti ammattitaitoinen

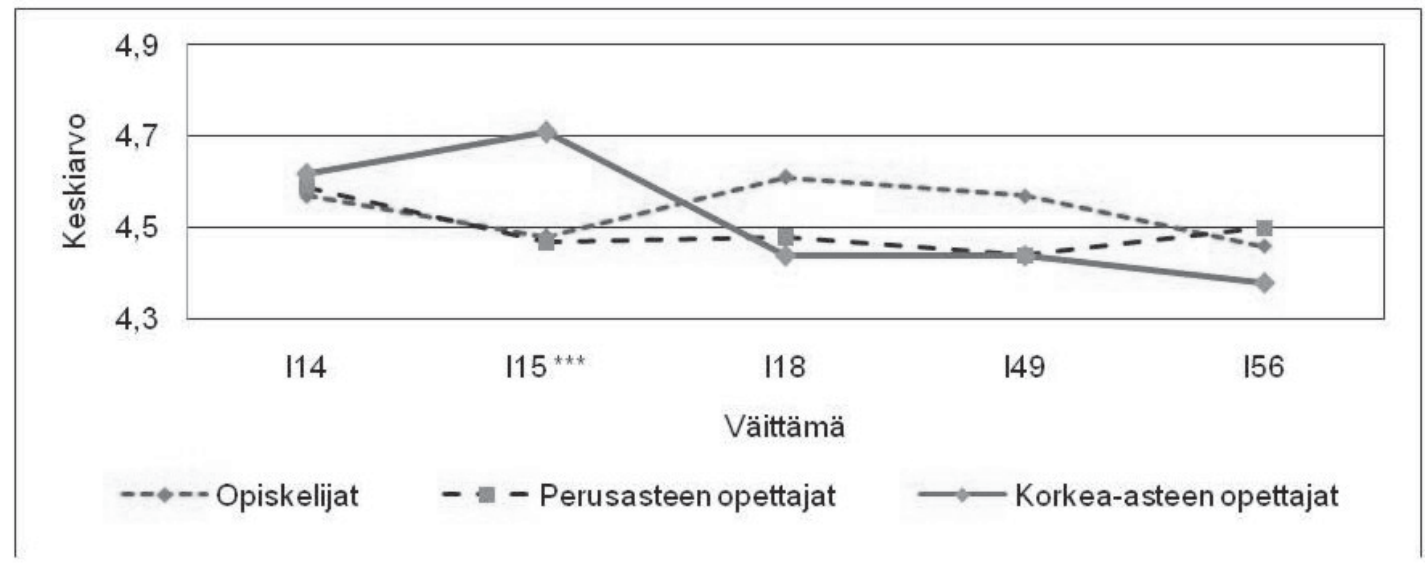

KUVIO 1. Innovatiivisen opettajan toimintaa parhaiten kuvaavat (suurimmat vastausten keskiarvot)

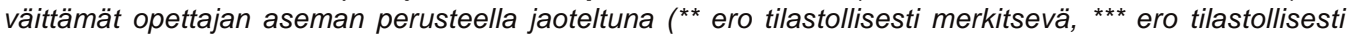
erittäin merkitsevä). 


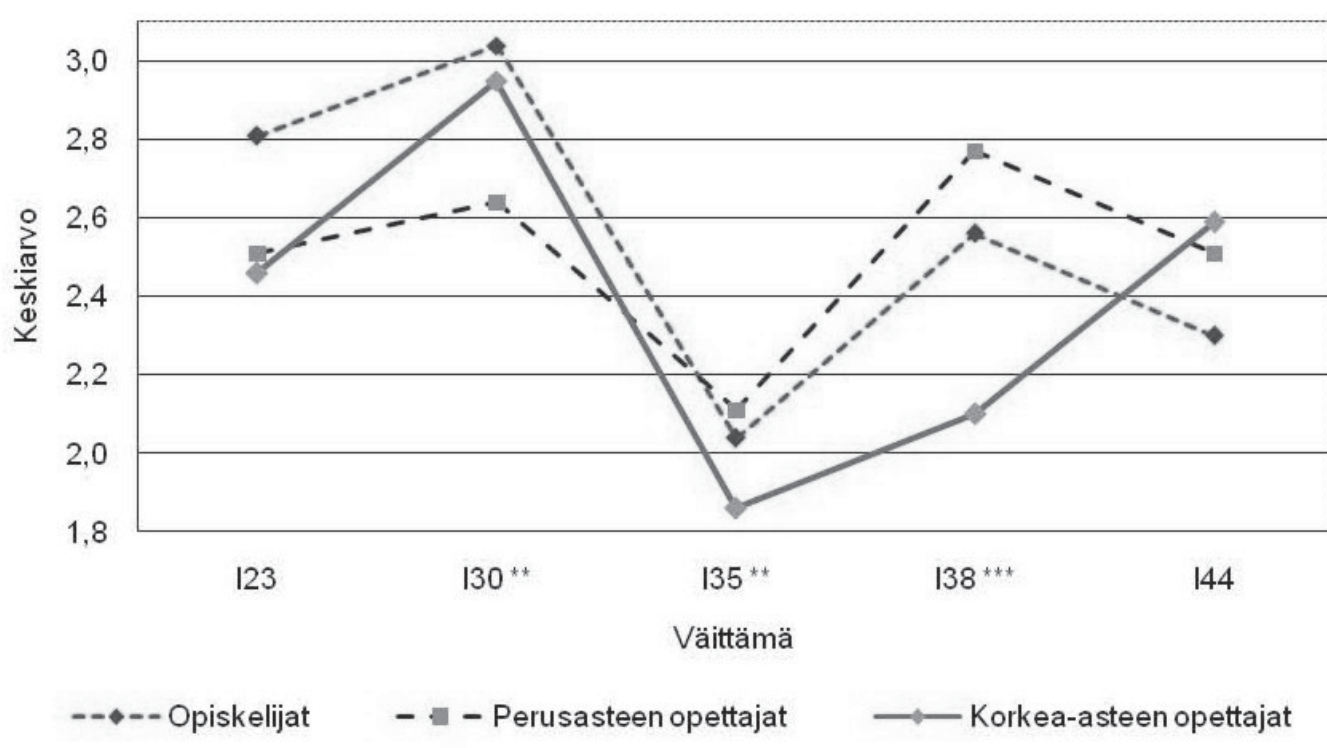

KUVIO 2. Opettajan innovatiivista toimintaa heikoiten kuvaavat (pienimmät vastausten keskiarvot) väittämät opettajan aseman perusteella jaoteltuna (** ero tilastollisesti merkitsevä, ${ }^{\star \star \star}$ ero tilastollisesti erittäin merkitsevä).

\section{Innovatiivinen opettaja}

(I23) on opetuksessaan arkipäiväinen

(I30) pyrkii toiminnassaan taloudellisuuteen

(I35) toimii opettajajohtoisesti

(I38) painottaa kuria ja järjestystä

(I44) painottaa palkitsemismenetelmiä

Heikoiten (pienin vastauskeskiarvo) opettajan toiminnan innovatiivisuutta osoittivat autoritääriseen toimintaan viittaavat piirteet. Pienimmän keskiarvon kaikista väittämistä sai opettajajohtoinen toiminta, varsinkin korkea-asteen opettajien vastauksissa. Kuri ja järjestys yhdistettiin vähänlaisesti innovatiiviseen opettajan toimintaan. Erityisesti perusasteen opettajat suhtautuivat epäilevästi taloudellisuuspyrkimykseen innovatiivisen opettajan toimintana.

Opettaja-asemaltaan erilaisten vastaajaryhmien (opettajaopiskelijat, perusasteen opettajat, korkeaasteen opettajat) erot olivat tilastollisesti merkitsevät tai erittäin merkitsevät neljässä väitteessä kymmenestä. Huomionarvoista on, että innovatiivisuutta parhaiten kuvaavista piirteistä korkeaasteen opettajat pitivät erilaisten toimintatapojen yhdistämistä vielä muita ryhmiä tärkeämpänä. Viidestä heikoiten opettajan innovatiivisuutta kuvaavasta piirteestä kolmessa oli vastaajaryhmien vä- lillä tilastollisesti vähintään merkitsevä ero. Perusasteen opettajat pitivät taloudellisuuspyrkimystä vielä vähemmän tärkeänä kuin muut vastaajaryhmät. Korkea-asteen opettajat pitivät vastaavasti yhtäältä opettajajohtoisuutta ja toisaalta kuria ja järjestystä vähemmän tärkeänä kuin muut vastaajaryhmät. Opettaja-aseman perusteella tehtyä jaottelua on esitelty kuviossa 1 ja kuviossa 2. Vastauksissa heijastunee jossain määrin eri oppilaitosten erilaiset perustehtävät. Perusasteella mukana on paljon runsaammin kasvatustavoitteita, kun taas korkea-asteella keskitytään erityisesti opettamiseen.

\section{Miesten ja naisten käsitykset innovatiivisen opettajan toiminnasta}

Eroavaisuuksia miesten ja naisten välisissä käsityksissä on mielenkiintoista tarkastella, sillä erityisesti liiketaloustieteissä innovatiivisuus ja innovaatiot näyttäytyvät hyvin miehisenä käsitteenä ja esimerkiksi patenteista, joita usein hyödynnetään innovaatio- ja innovatiivisuustutkimuksissa, valtaosa on miesten tekemiä. Sen sijaan opetus- ja kasvatusala on viime vuosikymmeninä yhä voimakkaammin naisistunut. Siksi onkin hedelmällistä tarkastella, onko löydettävissä eroja suku- 


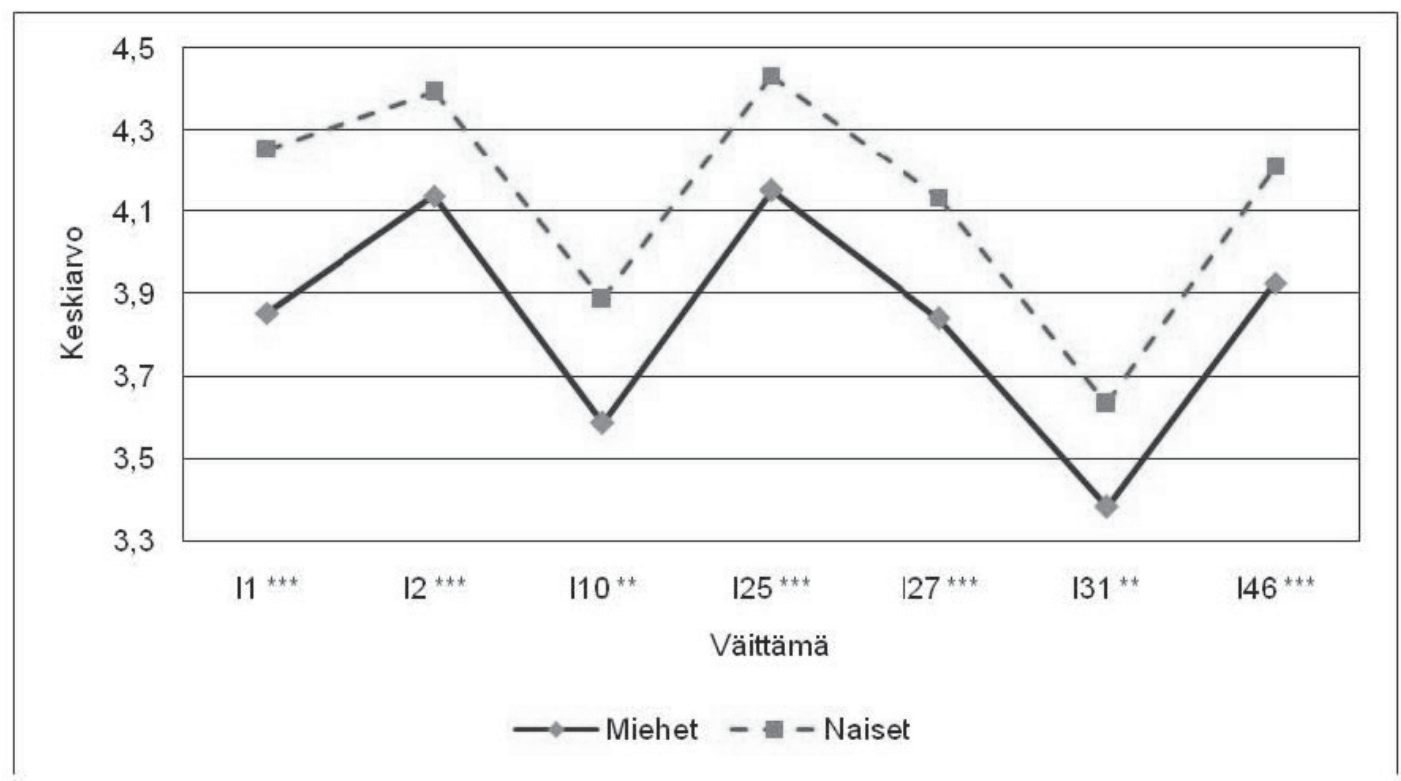

KUVIO 3. Miesten ja naisten väliset, tilastollisesti merkitsevät erot ryhmää ja yhteisöllisyyttä koskevissa väittämissä (** ero tilastollisesti merkitsevä, *** ero tilastollisesti erittäin merkitsevä).

puolten välillä käsityksissä opettajan innovatiivisesta toiminnasta.

Yhteensä 57 väittämästä kaikkiaan 17 väittämässä miesten ja naisten väliset erot olivat tilastollisesti erittäin merkitseviä ja yhteensä 39 väittämässä vähintään melkein merkitseviä. Nämä 39 väittämää on luokiteltu neljään ryhmään: 1) ryhmä-, 2) oppilas-, 3) keino- ja 4) opettajaväittämät. Ryhmittely on tehty sekä mittaria tehtäessä että analysoitaessa aiempaan tutkimuskirjallisuuteen perehtyen ja myös tutkijoiden ristiinkommentoinnin avulla. Osa väittämistä voisi sopia myös johonkin toiseen ryhmään, mutta tässä artikkelissa kukin väittämä on luokiteltu vain yhteen ko. ryhmistä. Faktorianalyysia ei tässä yhteydessä, aineistoa ensimmäistä kertaa tieteellisesti tarkasteltaessa tehty.

Ryhmään, ryhmädynamiikkaan ja yhteisöllisyyteen liittyviä ryhmäväittämiä oli kyselyssä yhteensä 10. Kuvioon 3 on näistä koottu tilastollisesti vähintään melkein merkitsevää sukupuolten keskiarvojen eroa ilmentäneet seitsemän väittämää (70 prosenttia ryhmän kaikista väittämistä). Suurin sukupuolten välinen ero tuli väittämässä, jonka mukaan opettajan innovatiivinen toiminta liittyy yhteistyön merkityksen korostamiseen työyhteisössä.

Kuvion 3 väittämät ovat seuraavat: Kun opettaja toimii innovatiivisesti, hänen toimintaansa voi kuvata seuraavasti:

\section{Innovatiivinen opettaja}

(I1) korostaa yhteistyön merkitystä työyhteisössä

(I2) korostaa vuorovaikutusta oppilaiden välillä

(I10) on yhteisön merkitystä painottava

(I25) painottaa oppimista enemmän kuin opettamista

(I27) edistää oppilaiden sosiaalistumista

(I30) huomioi toverisuhteiden merkitystä

(I46) painottaa keskustelun merkitystä opetuksessa

Oppilaaseen yksilönä liittyviä oppilasväittämiä oli kyselyssä kaikkiaan 11. Kuviossa 4 on näistä koottu tilastollisesti vähintään melkein merkitsevää sukupuolten keskiarvojen eroa ilmentäneet neljä väittämää (36 prosenttia kaikista ryhmän väittämistä). Naisten vastauksissa korostuivat varsinkin oppilaskeskeisyys ja oppilaslähtöisyys selvästi miesten vastauksia enemmän.

Kuvion 4 väittämät ovat seuraavat: Kun opettaja toimii innovatiivisesti, hänen toimintaansa voi kuvailla:

\section{Innovatiivinen opettaja}

(I36) toimii oppilaskeskeisesti

(I37) toimii oppilaslähtöisesti

(I45) luottaa oppilaiden itseohjautuvuuteen

(I48) korostaa eriyttämistä 


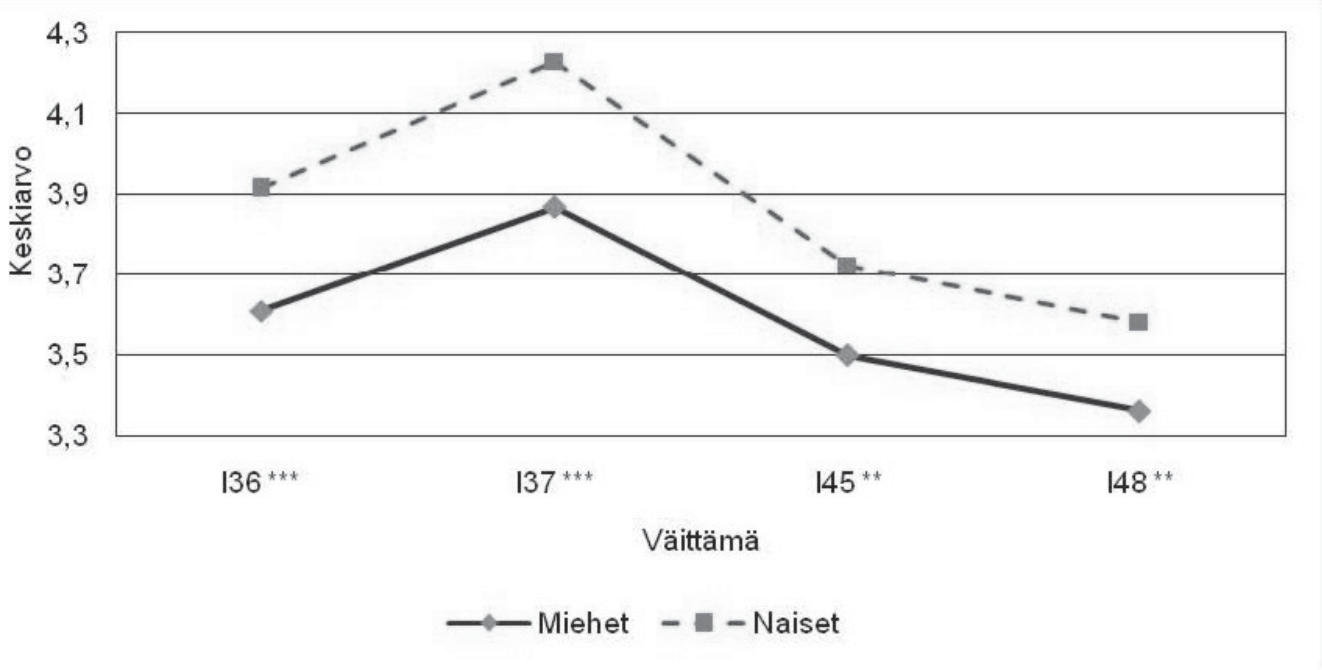

KUVIO 4. Miesten ja naisten väliset, tilastollisesti merkitsevät erot oppilaaseen keskittyvissä väittämissä ( ${ }^{\star \star}$ ero tilastollisesti merkitsevä, ${ }^{\star \star \star}$ ero tilastollisesti erittäin merkitsevä).

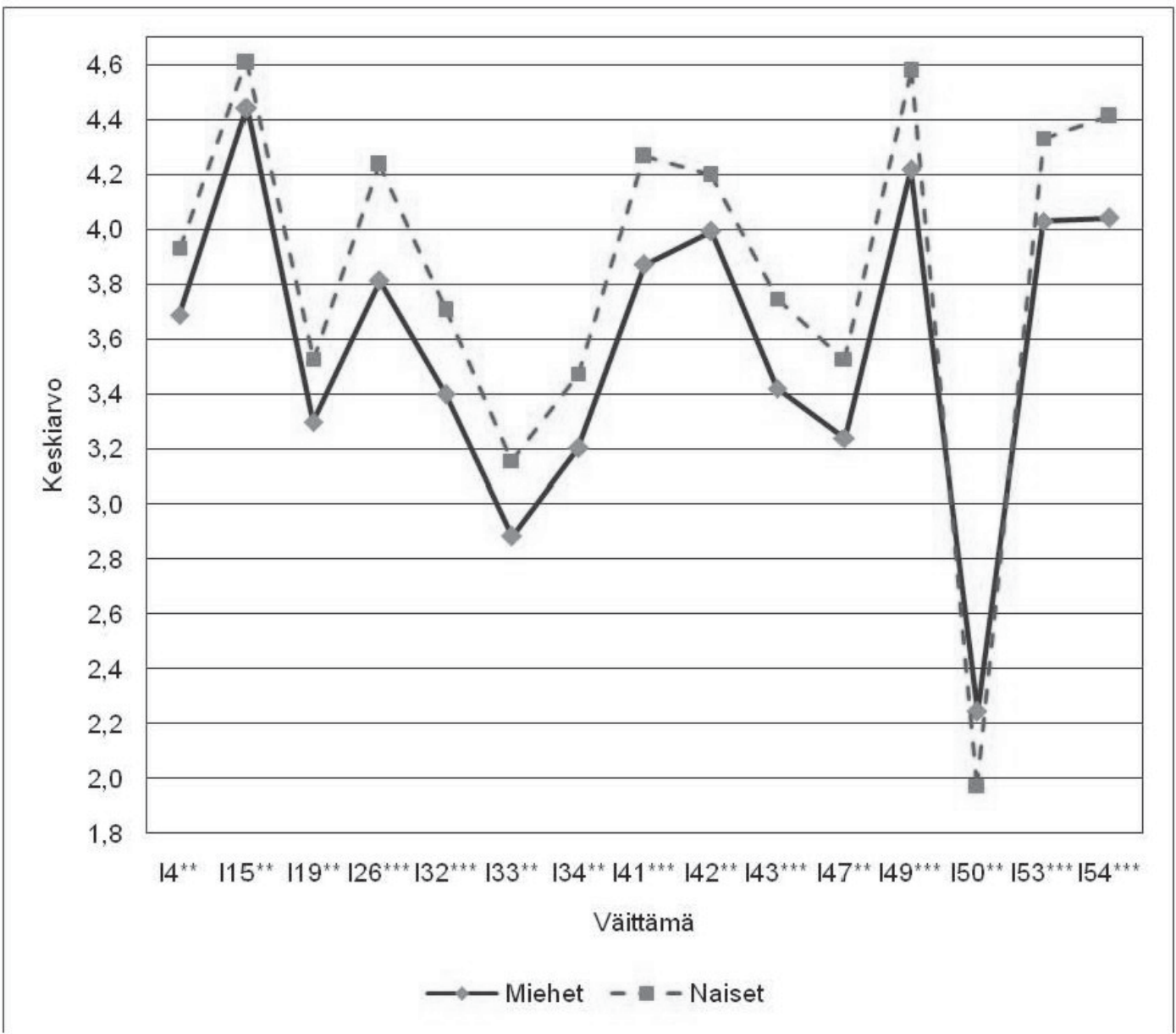

KUVIO 5. Miesten ja naisten väliset, tilastollisesti merkitsevät erot opetusmenetelmiä korostavissa väittämissä (** ero tilastollisesti merkitsevä, ${ }^{\star * \star}$ ero tilastollisesti erittäin merkitsevä). 
Keinoihin ja metodeihin liittyviä keinoväittämiä oli eniten, kaikkiaan 21. Kuviossa 5 on koottu kaikki tilastollisesti vähintään melkein merkitsevää sukupuolten vastauskeskiarvojen eroa ilmentäneet 15 keinoväittämää (71 prosenttia kaikista ryhmän väittämistä). Näistä yhdessä miesten vastauskeskiarvo oli suurempi kuin naisten. Miehet liittivät opettajan innovatiivisuuteen yhteen tai pariin opetusmenetelmään keskittymisen hieman naisia kiinteämmin. Ero sukupuolten välillä korostui siinä, että naiset antoivat kauttaaltaan suurempia arvioita eri metodeihin ja opetustyyleihin liittyviin väittämiin, kuten yhteistoiminnalliseen oppimiseen, konstruktivismiin ja ongelmaperustaiseen oppimiseen liittyviin väittämiin.

Kuvion 5 väittämät ovat seuraavat: Kun opettaja toimii innovatiivisesti, hänen toimintaansa voi kuvata seuraavasti:

\section{Innovatiivinen opettaja}

(I4) pyrkii jatkuvaan arviointiin

(I15) liittää yhteen erilaisia toimintatapoja

(I19) korostaa tutkimuksen merkitystä

(I26) painottaa elämyksellisyyttä

(I32) painottaa kulttuurin merkitystä

(I33) huomioi liiketalouden ja yrityskentän

(I34) korostaa yhteiskunnan merkitystä opetukses-

saan

(I41) käyttää yhteistoiminnallisia oppimismenetelmiä

(I42) käyttää ongelmaperustaista oppimista

(I43) korostaa konstruktivismin merkitystä

(I47) korostaa miellekartan käyttöä opetuksessa

(I49) käyttää monipuolisesti eri opetusmenetelmiä

(I50) panostaa yhteen tai pariin opetusmenetelmään

(I53) painottaa kokemuksellista oppimista

(I54) käyttää tutkivaa oppimista ja tutkimustehtäviä

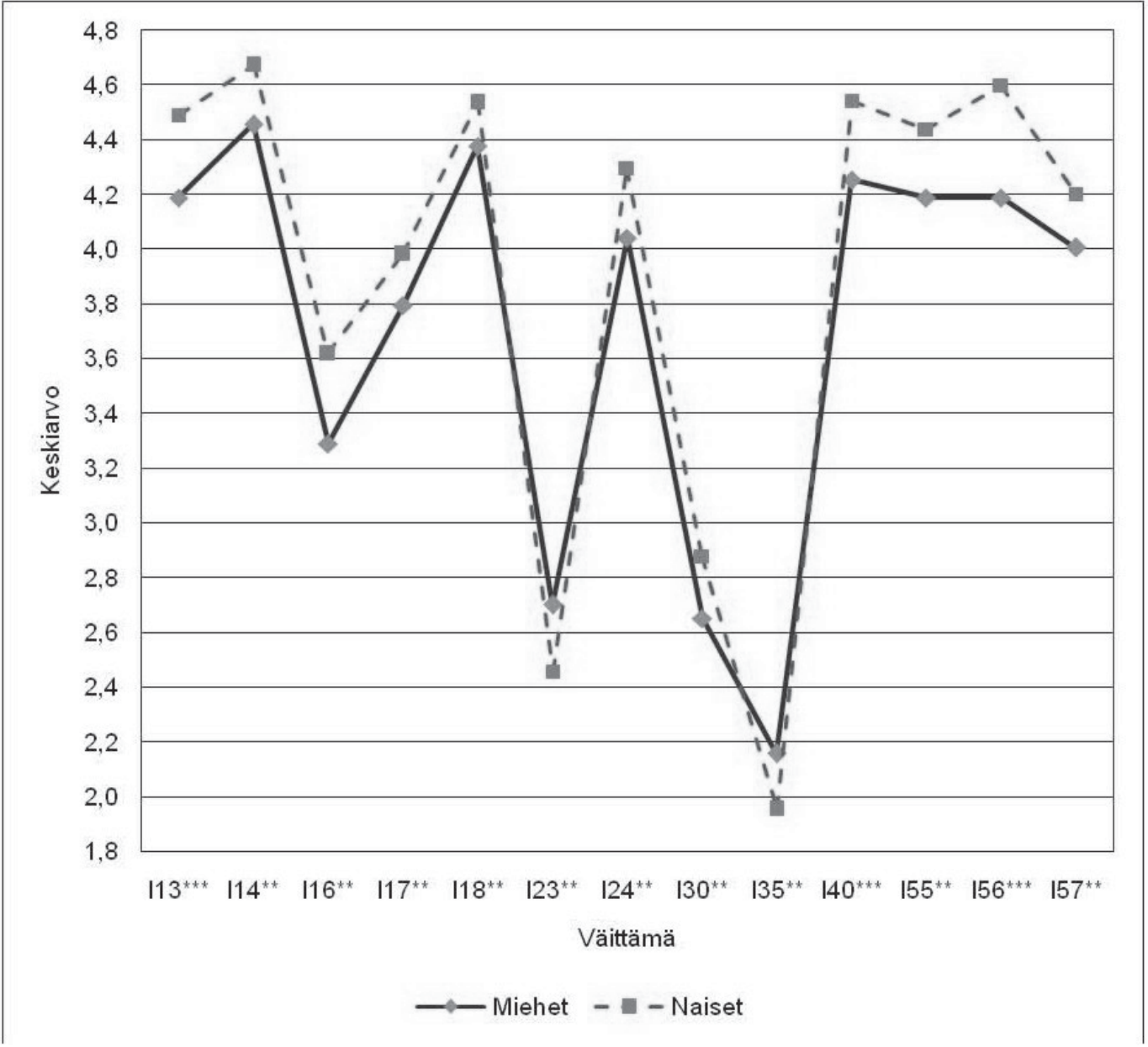

KUVIO 6. Miesten ja naisten väliset, tilastollisesti merkitsevät erot opettajan toimintaa fokusoivissa väittämissä (** ero tilastollisesti merkitsevä, *** ero tilastollisesti erittäin merkitsevä). 
Kuvio 6. Innovatiivinen opettaja

(I13) omaksuu helposti uusia työtapoja

(I14) uudistaa opetusmenetelmiään

(I16) painottaa ainutkertaisuutta

(I17) on päämäärätietoinen

(I18) on kekseliäs

(I23) on opetuksessaan arkipäiväinen

(I24) analysoi omia työ- ja toimintatapojaan

(I30) pyrkii toiminnassaan taloudellisuuteen

(I35) toimii opettajajohtoisesti

(I40) toimii persoonallisesti opetustyössään

(I55) on sitoutunut vahvasti opetustyöhön

(I56) on pedagogisesti ammattitaitoinen

(I57) on opettamansa aineen vahva osaaja

Erilaisiin, opettajaan itseensä, hänen persoonaansa ja henkilökohtaiseen osaamiseensa liittyviä opettajaväittämiä kyselyssä oli kaikkiaan 15. Kuviossa 6 on koottu tilastollisesti vähintään melkein merkitsevää sukupuolten vastauskeskiarvojen eroa ilmentäneet 13 opettajaväittämää (87 prosnettia ryhmän kaikista väittämistä). Näistä kahdessa (opettajajohtoisuus ja opetuksen arkipäiväisyys) miesten vastauskeskiarvot olivat suuremmat kuin naisten, mutta nämä liittyvät heikosti (pienet vastauskeskiarvot) innovatiivisuutta kuvaaviin piirteisiin. Naiset painottivat esimerkiksi uusien työtapojen omaksumista ja pedagogista ammattitaitoa.

Yhteenvetona voidaan todeta, että sukupuolten välisissä eroissa ilmeni selkeää systematiikkaa, sillä naisten keskiarvot olivat kolmea lukuun ottamatta kaikissa väittämissä miesten keskiarvoja suurempia. Miesten vastauksissa opettajan innovatiivisen toiminnan piirteinä korostuivat naisten vastauksia voimakkaammin opetuksen arkipäiväisyys, opettajajohtoisuus ja panostaminen yhteen tai pariin opetusmenetelmään. Kuitenkin myös miehet antoivat näille keskiarvoltaan pienempiä lukuarvoja. Opettajan innovatiivinen toiminta liittyy miesten vastausten perusteella enemmän tavanomaiseen, jokapäiväiseen opettajantyöhön. Naisten vastausten perusteella opettajan innovatiivinen toiminta liittyy erityisesti ammattitaitoon ja opettajaan itseensä.

\section{Pohdinta}

Jokapäiväisessä keskustelussa innovatiivisuus yhdistetään usein luovuuteen ja uudistuksiin ja innovatiivisuudesta on tullut muotikäsite, jota käytetään kepein perustein useilla eri yhteiskunnalli- sen keskustelun osa-alueilla. Liiketaloudessa innovaatiokeskustelu on melko miehistä ja esimerkiksi patenteista valtaosa on miesten tekemiä. Opetusala sen sijaan on vuosi vuodelta kehittynyt yhä naisvaltaisemmaksi. Tämän tutkimuksen tavoitteena oli tutkia, minkälaisen merkityksen opettajan innovatiivinen toiminta saa opetusalan asiantuntijoiden mielissä.

Näyttää siltä, että opettajan innovatiivisuuden katsotaan olevan yhteydessä uudistushenkisyyteen ja uudistuksiin. Tällainen merkitys käsitteelle annetaan yleensä myös teoreettisessa keskustelussa. Innovatiivisesti toimiva opettaja pyrkii uudistamaan opetusmenetelmiään jatkuvasti ja hän koettaa myös mahdollisuuksien mukaan yhdistää erilaisia työ- ja opetustapoja. Innovatiivisen opettamisen perusedellytyksenä on myös pedagoginen ammattitaito ja kekseliäisyys jokapäiväisessä työssä. Innovatiivisesti toimiva opettaja ei toimi autoritäärisesti vaan pikemminkin pyrkii tukemaan oppilaiden itsenäisyyttä, eikä hän käytä suoria rankaisu- tai palkitsemiskeinoja. Hänen toimintaansa ei ohjaa erityisesti pyrkimys taloudellisuuteen, eikä hän arkipäiväisty työssään.

Aiempia tutkimustuloksia siitä, miten opetusalan asiantuntijat ymmärtävät opettajan innovatiivisen toiminnan, ei juurikaan ole käytettävissä ja innovatiivisuus ymmärretään yleensäkin hieman hajanaisesti opetusalalla. Harrisin (2002) mukaan innovatiivisuudesta voidaan puhua vasta, kun esimerkiksi opettajien ja oppijoiden roolit on huomioitu, on todettavissa konkreettisia hyötyjä, vaikutus kestää ja innovaatio on siirrettävissä. Kokonaisuudessaan innovatiivisuus-käsityksiä ei ole riittävästi tutkittu, vaikka usein opetus- ja kasvatustehtäviä linjaavissa strategioissa painotetaan pyrkimyksiä innovatiivisuuteen ja innovatiiviseen toimintaan. Tiedossa on lähinnä se, miten innovatiivisuudeksi julkisuudessa esitetään erilaiset tekniset ratkaisut ja radikaalit muutokset.

Eri oppilaitostasoilla toimivat opettajat näyttävät ymmärtävän innovatiivisuuskäsitteen eri tavoin. Korkea-asteen opettajat pitivät muita vastaajaryhmiä tärkeämpänä innovatiivisen opettajan toimintana erilaisten toimintatapojen yhteen liittämistä ja oppiaineiden integrointia. Perusasteen opettajat korostivat korkea-asteen opettajia enemmän opettajajohtoisuutta sekä kuria ja järjestystä. Lienee selvää, että tässä heijastuivat eri oppilaitosten erilaiset perustehtävät, perusasteen kasvatuspainotteisemmat tavoitteet ja korkea-asteen koulutukseen tähtäävät tavoitteet. 
Hyvää opettajuutta on tutkittu vuosikymmenten aikana runsaasti, mutta innovatiivista opettajuutta paljon vähemmän. Opetusalalla innovatiivisuus ei välttämättä näytä olevan synonyymi pelkästään hyvälle opettajuudelle, eikä se missään tapauksessa ole vain uusien laitteitten kanssa työskentelemistä ja niiden soveltamista opetukseen. Opettajan innovatiivisuuteen käsitteenä ja varsinakin innovatiivisuuteen itseensä näytetään suhtautuvan sukupuolisidonnaisesti. Miesvastaajat pitivät lähes kauttaaltaan kaikkia innovatiivisuusväittämiä vähemmän kuvaavina, heidän vastauksensa saivat lähes kaikissa väittämissä naisvastaajia pienemmät keskiarvot. Naiset korostivat miehiä enemmän yhteistyön ja opettamisen kehittämisen merkitystä ja opettajan omaa toimintaa ja persoonaa.

Tulosten perusteella voi olla mahdollista, että miehet tulkitsevat innovatiivisuuden liittyvän pienempiin uudisteisiin naisten nähdessä innovatiivisuuden liittyvän radikaalimpiin, huomiota herättävämpiin piirteisiin. Miesten vastauksissa korostui opettajajohtoisuus ja arkipäiväisyys hieman naisia enemmän. On huomioitava, että esimerkiksi Heikkisen (2007) väitöstutkimuksen perusteella yrittäjänaiset ovat ideoivampia kuin yrittäjämiehet, eikä käsillä olevan tutkimuksen perusteella voida ottaa kantaa opetusalan asiantuntijoiden sukupuolten persoonallisuuseroihin. Siihen, heijastuiko Heikkisen esille tuoma sukupuolisidonnainen, persoonallisuuteen sidoksissa oleva ideoivuus tässä tutkimuksessa, ei voida ottaa kantaa. Tässä tutkimuksessa käytetyn mittarin sukupuolineutraaliutta on vaikea arvioida, mutta sen laadinnassa tavoitteena oli kattava kasvatustieteellistä ja liiketaloustieteellistä tietämystä huomioiva sukupuoliriippumaton mittari. Joka tapauksessa erilaiset käsitykset innovatiivisuudesta olisi syytä huomioida tarkasteltaessa innovatiivisuuden kehittämistä. Asia on tärkeä pohdittaessa sitä, millä tavoin sukupuolten välistä tasa-arvoa, jota usein tarjotaan keinoksi innovatiivisuuteen (ks. esim. CEMR 2006; Kuoppala ym. 2003), pyritään tukemaan käytännön innovatiivisuuden mahdollistamiseksi.

Innovatiivisuus näyttää saaneen jossain määrin erilaisen sävyn opetusalalla kuin mikä sillä perinteisesti on liike-elämässä. Liike-elämässä innovatiivisuus on symbioosissa taloudellisen tehokkuuden kanssa, mutta opetusalalla taloudellisuuspyrkimystä ei pidetä niin merkittävänä. Kuitenkin liike-elämän innovatiivisuudesta tutut kekseliäisyys, uudistusmielisyys, sopeutuvuus ja osallis- ten tarpeiden huomioiminen ovat vahvasti mukana innovatiivisuudesta keskusteltaessa myös kasvatus- ja opetusalalla. Jatkossa olisikin kiinnostavaa edelleen tutkia laajemmin sitä, miten eri tavalla innovatiivisuus ymmärretään eri yhteyksissä. Vasta laajentuneen ymmärryksen avulla voidaan täysipainoisesti panostaa innovatiivisuuden tukemiseen. Tulosten perusteella näyttää siltä, että innovatiivisuuteen pyrittäessä opettajankoulutuksessa olisi syytä pyrkiä parantamaan valmistuvien opettajien valmiuksia joustavuuteen ja avoimuutta uudistuksia kohtaan. Toisaalta herää myös kysymys, tulisiko uudistuksiin ja uudistushenkisyyteen kiinnittää entistä enemmän huomiota myös kasvatustieteellisessä tutkimuksessa.

\section{Lähteet}

Brown, J. S. (2006). New Learning Environments for the 21st Century. Exploring the Edge. Change. September/October 2006. 18-24.

Cherniss, C. \& Fishman, D.B. (2004) The Mesquite 'MicroSociety' school: identifying organizational factors that facilitate successful adoption of an innovative program. Evaluation and Program Planning 27 (1), 79-88.

CEMR (2006). The European Charter for Equality of Women and Men in Local Life. Council of European Municipalities and Regions. Innsbruck: CEMR

Ellis, A. K. (2005). Research on Educational Innovations, 4th Edition. Larchmont NY: Eye on Education.

Fullan, M. (1997). What's worth fighting for in the principalship. New York \& London: Teachers College Press.

Georgellis, Y., Joyce, P. \& Woods, A. (2000). Entrepreneurial Action, Innovation and Business Performance. The Small Independent Business. Journal of Small Business and Enterprise Development 7(1), 7-17.

Handfield-Jones, R., Nasmith, L., Steinert, Y. \& Lawn, N. (1993). Creativity in Medical Education: The Use of Innovative Techniques in Clinical Teaching. Medical Teacher 15 (1/ 1993), 3-10.

Harris, S. (2002). Innovative pedagogical practices using ICS in schools in England. Journal of Computer Assisted Learning (2002) 18, 449-458. 
Heikkinen, E. (2007). Yrittäjän persoonallisuus ja sen yhteys yrityksen kasvuun Big Five -teorian mukaan tarkasteltuna. Jyväskylä Studies in Business and Economics 60. Jyväskylä: Jyväskylän yliopisto.

Inkinen, K. (2000). Diffuusio ja fuusio. Osuuskauppainnovaation levinneisyys ja sen $d y-$ namiikka 1901-1998. Alueellisesti tulostuva näkökulma suomaisen osuuskauppatoiminnan kehitykseen ja sisällön muutokseen. Acta Universitatis Oeconomicae Helsingiensis A 181. Helsinki

Jackson, B. L. \& Kelley, C. (2006) Exceptional and Innovative Programs in Educational Leadership. Educational Administration Quarterly 38 (2), 192-212.

Kivisaari, S. (2004). Uusien innovaatioiden kaupallistaminen juurruttamalla. Teoksessa Heiskanen, E. (2004) (toim.). Ympäristö ja liiketoiminta. Arkiset käytännöt ja kriittiset kysymykset. Helsinki: Gaudeamus.

Kuoppala, M., Virtanen, P., Anttiroiko, A.-V. \& Pantzar, E. (2003), Haasteena sosiaalinen innovatiivisuus. Helsinki: Työministeriö.

Lam, A. (2004). Organizational innovation. In Fagerberg, J., Mowery, D. \& Nelson, R. (eds) Handbook of Innovation, Oxford University Press.

Lam, A. \& Lundvall, B.-A. (2007). The Learning Organisation and National Systems of Competence Building and Innovation. In Lorenz, N. \& Lundvall, B.-A. (eds.) How Europe's Economies Learn: Coordinating Competing Models. Oxford University Press. 110-139.

Nali, C. \& Lorenzini, G. (2004) Air quality survey carried out by schoolchildren: An innovative tool for urban planning. Environmental Monitoring and Assessment 131 (1-3), 201-210.

Opetusministeriö, (2007). Koulutus ja tutkimus vuosina 2007-2012. Helsinki: Opetusministeriö.

Paavola, R. (2007). Vankilaopetusta kehittämässä. Pelkääjävankien koulutus Sukevan vankilassa. Kehittämishankeraportti. Jyväskylä: Jyväskylän ammattikorkeakoulu.

Piva, M. \& Vivarelli, M. (2007). Is demand-pulled innovation equally important in different groups of firms? Cambridge Journal of Economics 2007, 31, 691-710.
Sheldon, K., Ryan, R., Rawshorne, L. \& Ilardi, B. (1997). Trait Slef and True Self. Cross-Role Variation in the Big Five Personality Traits and Its Relations with Psychological Authenticity and Subjective Well-Being. Journal of Personality and Social Psychology 73 (6), 1380-1393.

Siltala, R., Keskinen, S., Suomala, J. \& Taatila, V. (2008). Yhteistoiminnallinen oppiminen yrityksen innovaatioprosessissa. Työelämän tutkimus 1/2008. 44-55

Siltala, R., Luoto, A., Hakala, J. Suomala, J., Keskinen, S. \& Taatila, V. (2006). Liike-elämän ja opetusalan asiantuntijoiden näkemyksiä innovaatioista ja innovatiivisuudesta. Teoksessa Huttunen, A.-L. \& Kokkonen, A. M. (toim.) (2006). Koulutuksen kulttuurit ja hyvinvoinnin politiikat. Jyväskylä: Suomen kasvatustieteellinen seura. 456-466.

Siltala, R., Suomala, J., Taatila, V. \& Keskinen, S. (2007). Cooperative Learning in Finland and in California During the Innovation Process. In Andriessen D. (eds.) (2007). Intellectual Capital. Haarlem: Inholland University of Applied Sciences.

Singh, G., DeNoble, A. \& Kalousova, L. (2002). The Big Five Personality Factors and Entrepreneurial Intention. Frontiers of Entrepreneurship Research. Denver: University of Colorado at Denver.

Suomala, J., Taatila, V., Siltala, R. \& Keskinen, S. (2006). Chance Discovery as a First Step to Economic Innovation. CogSci/ICCS 2006. Sheraton Vancouver Wall Centre, Vancouver, British Columbia, Canada. 2204-2209.

Tenhunen, A., Siltala, R. \& Keskinen, S. (2009). Innovatiivisuuden käsite kansainvälisessä kasvatustieteellisessä tutkimuksessa ja suomalaisten opetusalan asiantuntijoiden käsityksissä. Teoksessa Heinilä, H., Kalli, P. \& Ranne, K. (toim.). (2009). Tutkiva oppiminen ja pedagoginen asiantuntijuus. Tampere: Topakka.

Venkatesh, V., Morris, M. G., Davis, G. B. \& Davis, F. D. (2003). User Acceptance of Information Technology. Toward a Unified View. MIS Quarterly 27 (3). 425-478

Artikkeli saapui toimitukseen 27.2.2009. Se hyväksyttiin julkaistavaksi toimituskunnan kokouksessa 27.5.2009. 